Economics of Public Health 



\title{
Economics of Public Health
}

Measuring the Economic Impact of Diseases

\author{
by \\ BURTON A. WEISBROD \\ Washington University \\ St. Louis
}

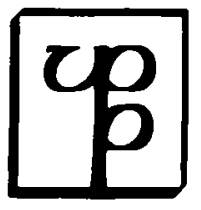

Philadelphia

University of Pennsylvania Press 
Copyright (C) 1961 by the Trustees of the University of Pennsylvania

Second Printing, 1968

Library of Congress Catalog Card Number : 61-5545

Printed in the United States of America 
TO MY FAMILY 
